\title{
DEVELOPMENT OF FORECASTING SYSTEM FOR ONION DOWNY MILDEW IN EGYPT
}

\author{
M.A. Afifi and Sahar A. M. Zayan \\ Plant Pathology Research Institute, Agricultural Research Center, Giza, \\ Egypt. E-mail: profmafifi@yahoo.com
}

\begin{abstract}
Onion (Allium cepa L.) is grown worldwide for its fleshy bulbs which are used as food and medicinal purposes. In Egypt, onion is the 2nd major export crop after cotton. Downy mildew of onion, caused by Peronospora destructor (Berk.)Casp. is considered one of the most destructive disease of onion and has a wide geographical distribution includes Egypt. P. destructor is a polycyclic pathogen: many infection cycles can follow one another during an onion-growing season. When weather conditions are favourable, the fungus can complete its cycle in a short time and the disease can cause severe yield losses and affect negatively the Egyptian national income. Therefore disease management relies on routine applications of both protectant and eradicant fungicides (4 - 6 sprays) throughout the season but maintaining control in the life of the crop and timing applications effectively is difficult. In addition, reducing fungicide applications on onions is extremely desirable for the environment and consumer. A computerized forecasting model for onion downy mildew named by the author (ODM-Cast ) was developed and field validated during 2006/2007 and 2007/2008 onion growing seasons in a disease hot spot cultivation site with a susceptible cultivar(Giza 20) and downy mildew disease severity was confirmed by the visual presence of leaves typical symptoms on onion plants in untreated plots. An advanced wireless telemetry Agro-weather station (Adcon A733 AddWave) which established within the crop canopy was used for monitoring the weather microelements such as: air temperature, relative humidity, leaf wetness, precipitation, global radiation and wind speed 24 hour a day. The results showed that ODM-Cast forecast model successfully indicated the disease daily infection potential and reduced the number of sprays in both years compared with the time table fundamental sprays in both 2006/2007 and 2007/2008, respectively. The basic roles of system analysis for model development and validation are discussed in details .
\end{abstract}

Key words: development of forecasting system, onion downy, Egypt.

\section{INTRODUCTION}

Onion (Allium cepa L.) is a bulbous crop widely cultivated in almost every country of the world. It is one of the important condiments being 
widely used either in green form or as mature bulb. In Egypt, onion is considered one of the most important vegetable crops cultivated all over the country, it is almost, becomes in third order among vegetable crops as for total cultivated area after tomatoes and potatoes. Also, onion is one of the most important exportable crops in Egypt (EL-Shraif,2003) where the annual onion exportation value during 2002- 2005 was 311,000 ton with return value of 30.3 million US\$ (Agric. Econ. Inst., 2006). Moreover the cultivated area of onion was increased from 1968 to 2006 by about 235\% (Agric. Econ. Inst., 2007). With respect to the magnitude of annual production of winter onion world-wide, Egypt has been tabulated as the fifth country following Japan, USA, Spain and Italy.

Downy mildew of onion caused by Peronospora destructor [Berk.] Casp. is an economically important and geographically widespread disease (Yarwood,1943 and Anonymous, 1978), causing losses in both yield and quality (Schwartz \& Mohan, 1995 and USDA, Crop Profile for Onion, 2003). Actual yield losses in bulb onions of 60 to $75 \%$ have been recorded (Develash \& Sugha, 1997).These losses mainly result from severe infection in bulb onion crops causing early defoliation, reduced bulb sizes, and poor storage quality of bulbs (Lorbeer \& Andaloro, 1984). Environmental conditions are mainly in charge of onion downy mildew progress operation, especially when relatively cool, moist weather prevails (Hildebrand and Sutton, 1982). In Egypt, such disease is the most prevalent and deleterious foliar disease presenting a real threat to the productivity of onion crop both in quantity and quality (Elewa, 1970 and Abdel-Megid et al., 2001).

The principal mean of controlling onion downy mildew is by applying fungicides and the efficiency of protection means depends on their application time and disease development level.

Generally, preventive fungicide sprays are scheduled 7-10 days apart to control downy mildew and to ensure good yields and high crop quality (Palti, 1989 and Wright et al., 2002).On the other hand, fungicide applications undertaken during unfavourable weather conditions for infection and disease spread are economically and ecologically superfluous. A reduction in the number of fungicide applications, while maintaining disease control, could be achieved by applying fungicides only at times when conditions are favorable for disease development. Because of environmental, public health, economic, and farm-management considerations concerning unnecessary fungicide use, methods should be developed for timing fungicide applications that provide acceptable control of onion downy mildew while reducing the frequency of fungicide use when possible.

Recent innovations in weather data collection, the use of onsite realtime automated (Telemetry) weather station to collect hourly plant canopy microclimate data via telephone modems or by radio telemetry to personal 
computers, and then the data need to be run through the computer forecasting simulation models. Several studies have been conducted around the world to forecast the appropriate time for the fungicide applications to wisely control onion downy mildew with no hazards to the human and environment and to avoid the misuse of such unnecessary applications at the same time (Jesperson and Sutton, 1987; Battilani et al., 1995; De Visser, 1998; Harper, 1998; Friedrich et al., 2003; Gilles et al., 2004 and Scott et al., 2008). The computerized model ODM-cast simulates the development of onion downy mildew on the basis of short-term observation of microclimatic factors. The inputs variables to the model are: temperature, $\mathrm{RH}$, precipitation, leaf wetness, global radiation and wind speed, to define the daily disease infection potential (DDIP). A complete onion downy mildew forecasting system would therefore develop a model predicting sporulation, infection, and latent period.

The present investigation was targeted to develop and validate ODM-cast, the first Egyptian computerized forecasting model, to allow direct use of the model in an experimental commercial onion open fields over two successive seasons 2006/2007 and 2007/2008 in Egypt. To detect correct time for the first spray and lead the fungicides application throughout the season for perfect disease control compared with time table recommended fungicide application, for each year of model validation. Finally, to establish such disease forecast system for onion downy mildew in Egypt.

\section{MATERIALS AND METHODS}

\section{Weather monitoring:}

Adcon A733 AddWave, an on-site automatic, telemetry, portable and solar powered agric-weather station Figure (1) was used to monitor and synchronize the microclimatological elements 24 hours a day. Advanced, sensitive sensors transmitted the digital data up to $20 \mathrm{~km}$ in distance, on average every 15 minutes, via a personal computer using radio waves. In this way, data on temperature, relative humidity, wind speed, leaf wetness, precipitation and global radiation were collected from onion canopy. The station is equipped with central base station Figure (2), which served as a: data collection center (receiver) to receive and save the collected data up to 50 days and to run advantage software which allowed simple interpretation of the readings using a graph and detailed list of chosen items.

\section{Onion downy mildew forecast model:}

A computerized simulation model named by the author ODMCast,(Figure 3) was designed and tested several times under laboratory conditions (computer workstation) before switching to the validation experimental phase conducted in a cool, wet weather in commercial fields at Howsh - Essa (Behera Governorate) throughout both 2006/2007 and 


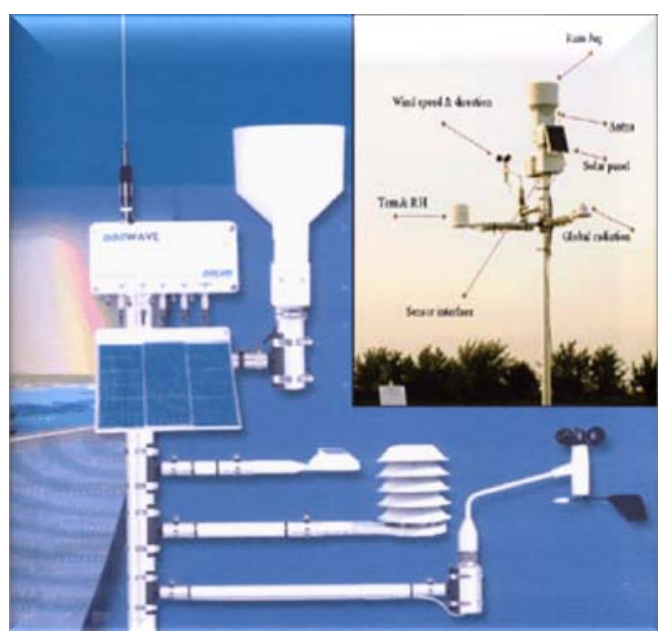

Figure1. Automated in crop weather station (Adcon A733).

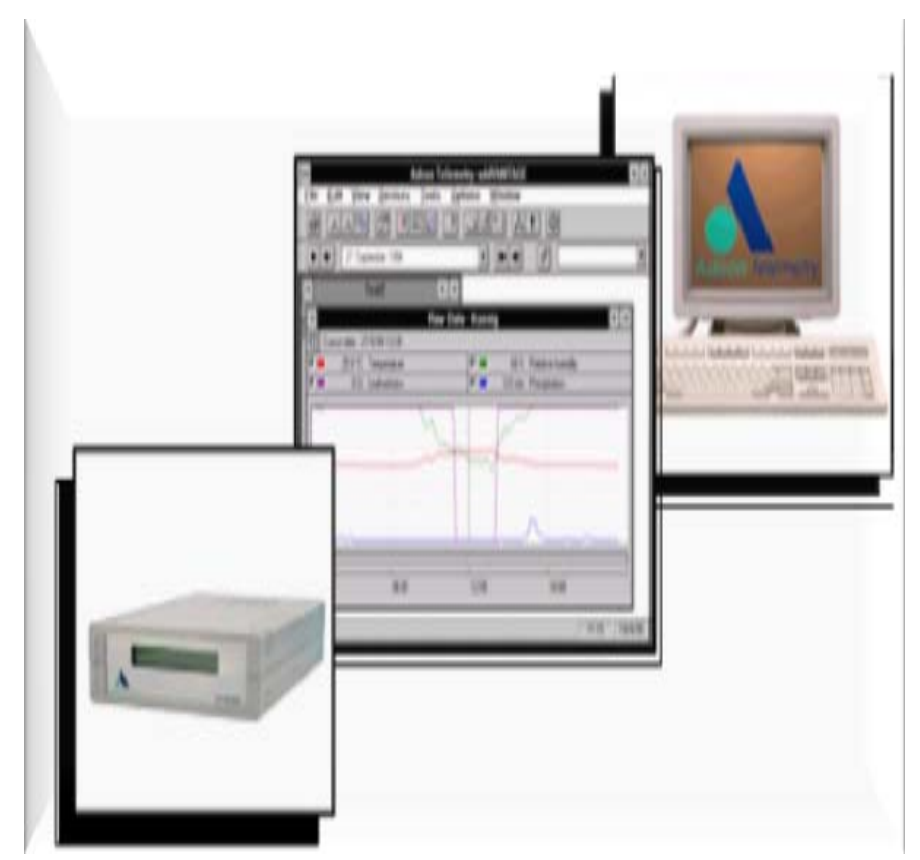

Figure 2. The base station (Receiver, PC, and Advantage Software) Data is instantly plotted for easy examination of weather data. Time line indicates values where it intersects data lines. 
ONION DOWNY MILDEW FORECAST MODEL

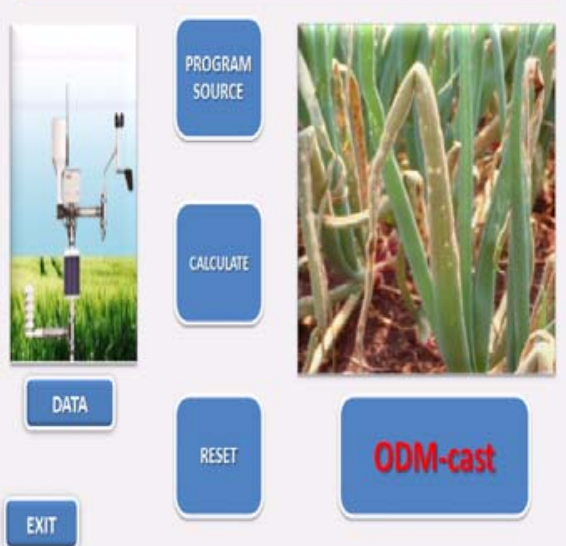

Figure 3. ODM - Cast model`s interface for onion.

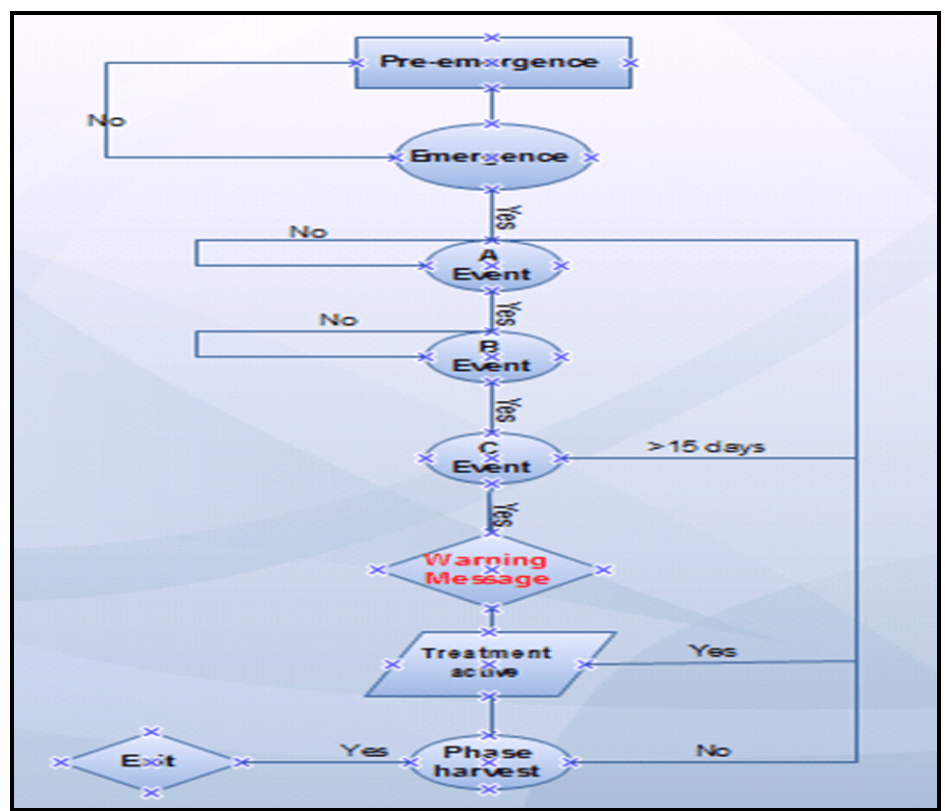

Figure 4. Flowchart of ODM-Cast model's downy mildew in Egypt. system analysis. 
2007 / 2008 onion successive growing seasons. This permitted us to figure out how well such a model predicted sporulation, infection and latent periods, on other hand to facilitate revision and refinement of the model based on these findings. Frequently, disease control (timing of sprays) of onion treated according to the model recommendations were compared to disease managed by traditional time-table spray schedules.

\section{The model system analysis:}

ODM-Cast model, presented as a flowchart is a creation and designation of a computerized simulation model, based on daily short-term observations (hourly weather data) analyzing the correlation between the input variables of microclimatological factors such as: temperature, relative humidity, leaf wetness, precipitation global radiation, wind speed. The model use these factors to calculate the actual time of primary and secondary daily disease infection potential (DDIP) of onion downy mildew causal agent Peronospora destructor. Then, the model outputs a daily announcement as a warning message (spray or don't spray) to guide the fungicides application for perfect disease control in the appropriate time. The model evaluation follows the basic rules of system analysis to identify events (A, B and C) for spore production, infection and latent period, respectively.

The model is activated at pre-emergence phase, and tries to detect the event $\mathrm{A}$ and $\mathrm{B}$ which is defined as: Event $\mathrm{A}$ is triggered when the model detects at least $X$ accumulated dynamic summation hours of $\mathrm{RH}>94$ and temperature between $\mathrm{Y}$ and $\mathrm{Z}$ according to the data tabulated in Table (1). While event $\mathrm{B}$ is triggered when the model detects at least $\mathrm{X}$ accumulated dynamic summation hours of $\mathrm{RH}=100$ and leaf wetness $>60 \mathrm{U}$ and / or precipitation $>0.1 \mathrm{~mm} /$ hour and temperature between $\mathrm{Y}$ and $\mathrm{Z}$ according to the data tabulated in Table 2. Then the model looks for event $\mathrm{C}$ which is defined when the model detects at least $X$ accumulated dynamic summation daily averages of $\mathrm{RH}>80$ and temperature between $\mathrm{Y}$ and $\mathrm{Z}$ according to the data tabulated in Table 3. Moreover, using the model system analysis brings an extension to the model, that applies the same rules not only to identify the first critical phase of the season (correct time for primary infection), but also to issue warnings for secondary daily disease infection potential (DDIP) throughout the whole growing season.

\section{Model validation:}

Field trials were carried out at Howsh-Essa (Behera Governorate) during two successive growing seasons; $2006 / 2007$ and 2007/ 2008 in commercial onion fields of susceptible cultivar (Giza 20), to develop and validate the ODM-Cast model in controlling onion downy mildew compared with time table fungicides sprays. The field trials were designed as 
Table 1. The basic rules of system analysis to identify event $A$.

\begin{tabular}{|c|c|c|c|c|}
\hline $\begin{array}{l}Y=\quad \text { Temp. } \\
\text { From: }\end{array}$ & $\mathrm{Z}=$ Temp. To: & $\begin{array}{l}X=6 \\
\text { of } R H\end{array}$ & $\begin{array}{l}X=8 \text { hours of } \\
\text { RH }\end{array}$ & $\begin{array}{l}X=10 \text { hours } \\
\text { of } R H\end{array}$ \\
\hline $8 \mathrm{C}$ & $12 \mathrm{C}$ & $\begin{array}{l}\text { Event } \\
\text { detected }\end{array}$ & & \\
\hline $13 \mathrm{C}$ & $17 \mathrm{C}$ & & $\begin{array}{l}\text { Event } \\
\text { detected }\end{array}$ & \\
\hline $18 \mathrm{C}$ & $22 \mathrm{C}$ & & & $\begin{array}{l}\text { Event } \\
\text { detected }\end{array}$ \\
\hline
\end{tabular}

Table 2. The basic rules of system analysis to identify event $B$.

\begin{tabular}{|c|c|c|c|c|}
\hline $\begin{array}{l}\mathrm{Y}=\text { Temp. } \\
\text { From: }\end{array}$ & $\mathrm{Z}=$ Temp. To: & $\begin{array}{l}X=2 \\
\text { of } R H\end{array}$ & $\begin{array}{ll}X=4 & \text { hours } \\
\text { of } R H & \end{array}$ & $\begin{array}{ll}X=6 & \text { hours } \\
\text { of } R H & \end{array}$ \\
\hline $10 \mathrm{C}$ & $13 \mathrm{C}$ & $\begin{array}{l}\text { Event } \\
\text { detected }\end{array}$ & & \\
\hline $14 \mathrm{C}$ & $17 \mathrm{C}$ & & $\begin{array}{l}\text { Event } \\
\text { detected }\end{array}$ & \\
\hline $18 \mathrm{C}$ & $21 \mathrm{C}$ & & & $\begin{array}{l}\text { Event } \\
\text { detected }\end{array}$ \\
\hline
\end{tabular}

Table 3. The basic rules of system analysis to identify event $C$.

\begin{tabular}{|c|c|c|c|c|}
\hline $\begin{array}{l}Y=\text { Temp. } \\
\text { From: }\end{array}$ & $\begin{array}{ll}Z= & \text { Temp. } \\
\text { To: } & \end{array}$ & $\begin{array}{ll}X= & 5-10 \\
\text { day of } & R H\end{array}$ & $\begin{array}{l}X=10-15 \\
\text { day of } R H\end{array}$ & $\begin{array}{l}X=>15 \text { day } \\
\text { of } R H\end{array}$ \\
\hline $17 \mathrm{C}$ & $20 \mathrm{C}$ & $\begin{array}{l}\text { Event } \\
\text { detected }\end{array}$ & & \\
\hline $13 \mathrm{C}$ & $16 \mathrm{C}$ & & $\begin{array}{l}\text { Event } \\
\text { detected }\end{array}$ & \\
\hline $10 \mathrm{C}$ & $12 \mathrm{C}$ & & & $\begin{array}{l}\text { Event } \\
\text { detected }\end{array}$ \\
\hline
\end{tabular}


randomized complete blocks and the area of each plot was $10.5 \mathrm{~m}^{2}(3.5 \times 3.0$ $\mathrm{m})$. Four replicates were used for each treatment and non-treated plots (sprayed with only water) served as controls. The following two treatments were tested: (i) a full-schedule fungicide program, in which plants were sprayed every 10 to 15 days, started at the second week of December; and (ii) spraying when the ODM-Cast forecasting model indicated that a spray application was needed and at least 15 days had elapsed since the previous fungicide application. Moreover , Ridomil plus 50\% WP ( Metalaxyl + copper ) $250 \mathrm{gm} / 100 \mathrm{~L}$ water is considered an effective recommended fungicide for controlling onion downy mildew in Egypt (Abdel-Megid et al.,2001), and this was used with both the ODM-Cast forecasting model announcement recommended treatments and the time-table schedule program. Weekly onion field inspection was initiated to ensure clear detection of the early sign of downy mildew. Microclimate weather data were automatically collected 24 hours a day by the advanced telemetry weather station (Adcon A733), established within the onion field canopy. Disease severity was measured 15 days after the last spray using a randomized sample of one hundred leaves from every plot, control efficacy of both treatments was recorded according to (Horsfall \& Barrat, 1945).

\section{RESULTS}

The results of such research figured out that the ODM-Cast (as named by the author) simulation computerized forecast model for onion downy mildew, which was designed using the roles of system analysis, was successfully developed and facilitate validated in Egypt for the first time, under onion open field conditions and minimized the number of fungicide applications for effectively management of downy mildew compared with a time-table schedule (10-15 day sprays) fungicide program. Data presented in Figures 5 and 6 pointed out that ODM-Cast model has clearly defined the appropriated time for the first spray in $21^{\text {st }}$ Dec.2006 and in $23^{\text {rd }}$ Dec.2007 respectively. The model output daily announcement with a consideration of the disease latent period, also successfully detected the secondary daily disease infection potential (DDIP) in $4^{\text {th }}, 17^{\text {th }}$ Jan., $6^{\text {th }}, 14^{\text {th }}$ Feb. .2007 and in $30^{\text {th }}$ Dec.2007, $13^{\text {th }}, 20$ th, 31 st Jan., while there were no warning message in Feb. 2008, respectively. Therefore, three sprays were applied in each season of model development according to the recommendation of ODM-Cast forecasting system, instead of seven sprays in 2006/2007 and eight sprays in 2007/2008 following a time-table schedule fungicide program. Moreover, both of the experimental treatments practically gave a sufficient management of onion downy mildew. 


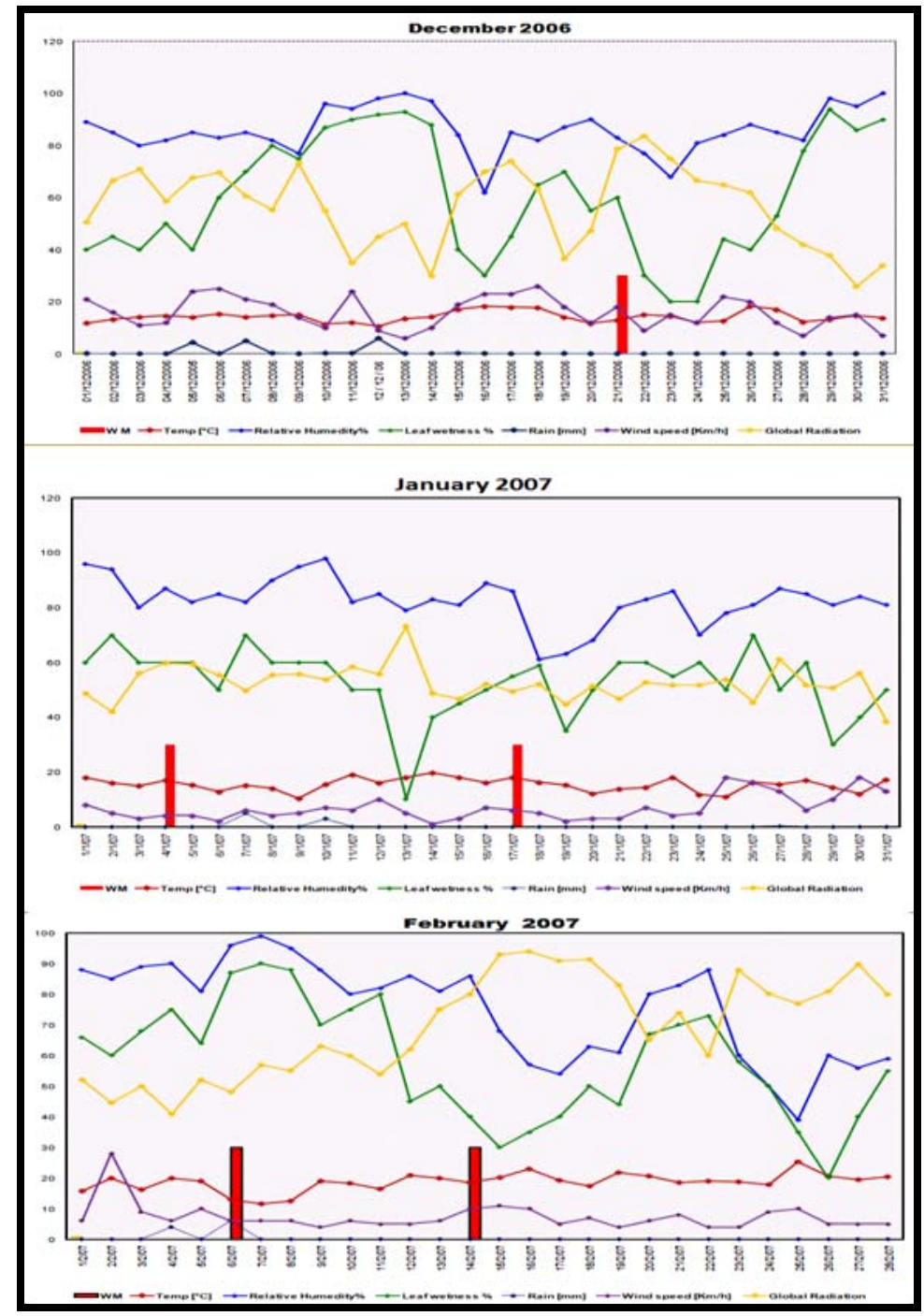

Figure 5 : The daily microclimatological factors (ODM-Cast model input variables ) during December, January and February of 2006/2007 onion-growing season, indicate the warning message of forecast system spray recommendations. 


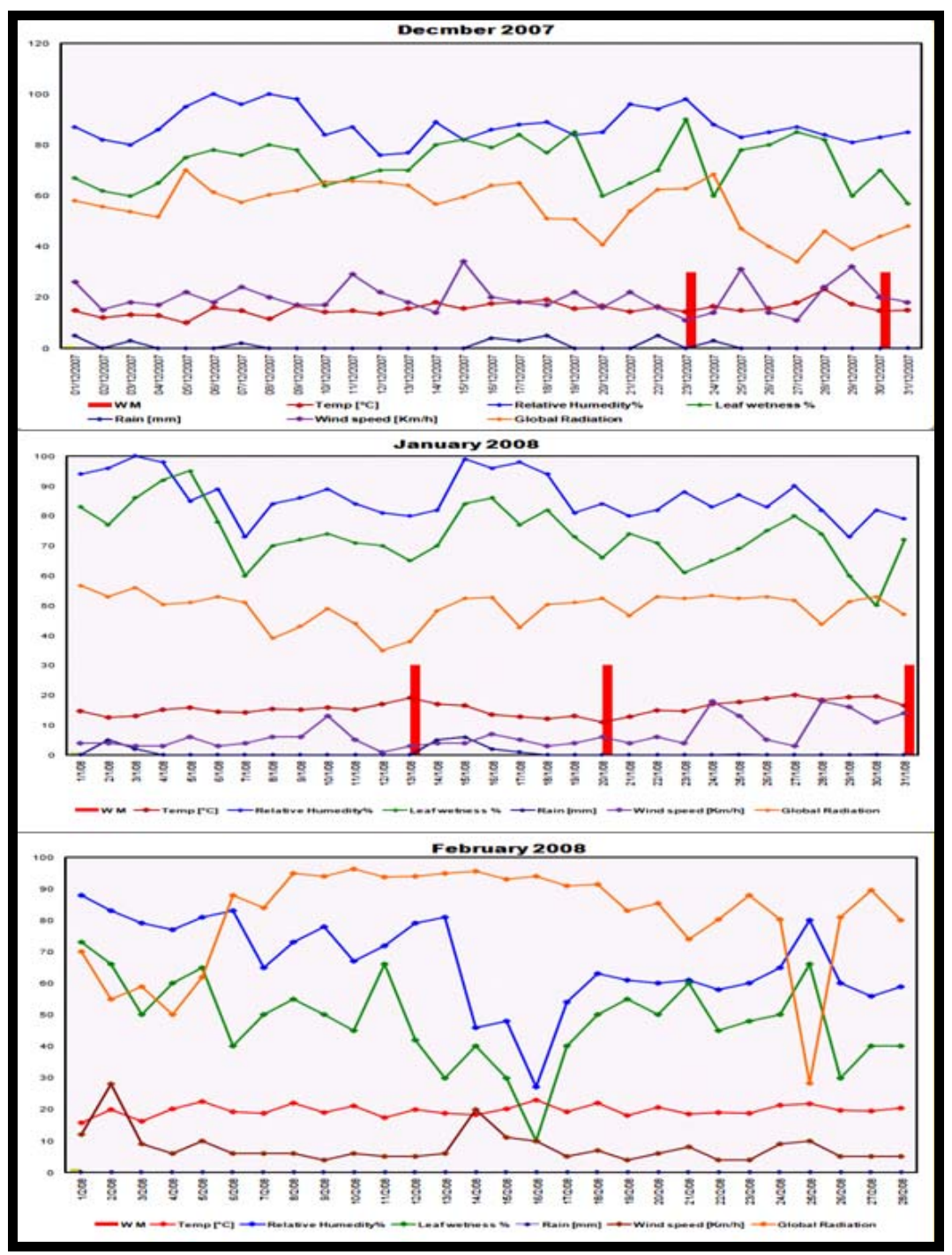

Figure6 : The daily microclimatological factors (ODM-Cast model input variables) during December, January and February of 2007/2008 onion-growing season, indicate the warning message of forecast system spray recommendations.

\section{DISCUSSION}

Downy mildew of onion caused by Peronospora destructor [Berk.] Casp. is considered one of the most destructive diseases for onion crop production, in addition affect positively the Egyptian national income by limiting the onion crop export operation. Most of agriculture practice had 
been used to control onion downy mildew in Egypt is derived from studies that mainly relay on the fungicide management scheme of time-table schedule application. Fungicides are often applied prophylactically by spraying every 10-15 days to control onion downy mildew, the amount of fungicides sprayed to control this disease needs to be reduced to minimize the risk to the environment. A reduction in the number of fungicide sprays could be achieved by spraying according to weather-based disease forecasting. An Egyptian forecasting system, named by the author ODM-Cast model, summarizes weather conditions that allow the infection cycle of $P$. destructor to proceed with a consideration of latent period. ODM-Cast follows the role of system analysis to accumulate and correlate the specific microclimatological elements that affect the development of certain disease into a computer-based model and then forecast the disease under different environmental conditions has been discussed here in detail.

Downy mildew usually appears in northern delta of Egyptian onion crops in December or January and fungicide programs against downy mildew generally begin between mid-December and the first of January. This study suggested that the ODM-Cast model criteria could be used to initiate the fungicide program at the time of the first sporulation-infection period, according to accurate and successful prediction of both primary infection and the daily disease infection potential (DDIP) by the ODM-Cast model developing and validating in two onion growing seasons during (2006/2007 and 2007/2008). Worldwide, many scientific considerable efforts has gone in the study of forecasting models for the simulation of onion downy mildew development towards better disease management with less human and environment hazards (Jesperson and Sutton, 1987; Battilani et al., 1995; De Visser, 1998; Harper, 1998; Friedrich et al., 2003; Gilles et al., 2004 and Scott et al., 2008).

Given results have an agreement with the mentioned studies and suggest that onion downy mildew could be manage in Egypt with fewer fungicide sprays a noticeable reduction in fungicide application was achieved. The number of sprays was reduced by $57 \%$ and $62.9 \%$ during $2006 / 2007$ and 2007/2008 onion-growing seasons, respectively using disease forecasting system compared with a time-table fungicide schedule. This study presents an Egyptian first step in developing disease forecasts to help onion crop growers to improve the efficiency of fungicides use by allowing more precise fungicide timing. 


\section{REFERENCE}

Abdel-Megid, M.S.; Mitwally, A.H.; Abdel-Momen, S. and Hilal, A.A.(2001). A preliminary field study on the possibility of controlling foliar disease of onion using some Egyptian medicinal plant extracts in comparison with a fungicide. Egypt. J. Phytopathol.,29 (1): 21-31.

Agriculture. Economic Institute (2006). The Indicator of Importing and Exporting of Agricultural Crops. Annual Agriculture Economy Book (Arabic Text book).

Agriculture . Economic Institute (2007). Cultivated crops production and annual consumption. Annual Agriculture Economy Book (Arabic Text book).

Anonymous (1978). Distribution maps of plant diseases, map no. 76, Peronospora destructor (Berk.) Casp. $4^{\text {th }}$ ed. CMI, Kew, UK.

Battilani, P.; Rossi, V.; Racca, P. and Giosue, S. (1995). ONIMIL, a forecaster for primary infection of downy mildew of onion, EPPO Conference on Forecasting in Plant Protection, Potsdam (DE).

Battilani, P.; Rossi, V.; Racca, P. and Giosue, S. (1998). A warning system for downy mildew infection on onion. Atti del $7^{\text {th }}$ International Congress of Plant Pathology, Edimburgh (UK),

Develash, R. K. and Sugha, S. K. (1997). Incidence of downy mildew and its impact on yield. Indian Phytopathology. 50: 127-129.

De Visser, C. L. M. (1998).Development of a downy mildew advisory model based on downcast. European Journal of Plant Pathology, 104:933943

Elewa, I.S. (1970). Studies on downy mildew disease of onion in U.A.R. Ph. D. Thesis, Fac.,Agric., Ain Shams Univ.

EL-Shraif, A.(2003). Economic Potential for Promotion of Egyptian Onions Exports. Mansoura Univ., J. Agric. Sci., 28(8):6171-6179.

Friedrich, S.; Leinhos, G.M.E. and Lopmeier, F. J. (2003).Development of ZWIPERO, a model forecasting sporulation and infection periods of onion downy mildew based on meteorological data. European Journal of Plant Pathology, 109: 35-45.

Jesperson, G.D. and Sutton, J.C. (1987). Evaluation of forecaster for downy mildew of onion (Allium cepa L.). Crop Protection, 6(2): 95103.

Gilles, T.; Phelps, K.; Clarkson, J. P. and Kennedy, R. (2004). Development of MILIONCAST, an improved model for predicting downy mildew sporulation on onions. Plant Dis. 88:695-702.

Harper, S.M.(1998). Forecasting onion downy mildew in the Lockyer Valley. Onions Australia, Vol. 15: 39-43. 
Hildebrand, P.D. and Sutton, J.C. (1982). Weather variables in relation to an epidemic of onion downy mildew. Histopathology, 72:219-224.

Horsfall, J.G. and Barrat, R.W.(1945).An improved grading system for measuring plant diseases. Phytopathology, 35:655.

Lorbeer, J. and Andaloro, J. (1984). Diseases of Onions. Downy Mildew. Nyaes,Geneva,NY.

http://www.nysaes.cornell.edu/ent/hortcrops/english/dmildew.html

Palti, J. (1989). Epidemiology, prediction and control of onion downy mildew caused by Peronospora destructor. Phytoparasitica, Vol. 17, p. 31-48.

Schwartz, H. F. and Mohan, S. K.(1995). Compendium of Onion and Garlic Diseases. American Phytopathological Society, St. Paul, MN.70 p.

Scott, J.B., Hay, F. S. and Wilson, C.R. (2008). Adaptation of the Forecasting Model DOWNCAST for Determination of Downy Mildew Epidemics of Oilseed Poppy in Tasmania, Australia. Journal of Phytopathology, 156(4):205-213.

USDA, Crop Profile for Onion, http://pestdaa.ncsu.edu/cropprofiles/docs/- txonions.html.

Wright, P. J.; Chynoweth, R. W.; Beresford, R. M. and Henshall, W. R. (2002).Comparison of strategies for timing protective and curative fungicides for control of onion downy mildew(Peronospora destructor) in New Zealand. Proceeding of BCPC Conference Pests and Diseases, pp 207-212.

Yarwood, C. E. (1943). Onion downy mildew. Hilgardia, 14:595-691. 


\section{تظوير نظام التنبؤ المرضى (اودم ـ كاست ) لمرض البياض

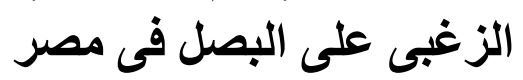

\section{محسن عبد الرازق عفيفي - سحر عبده زيان

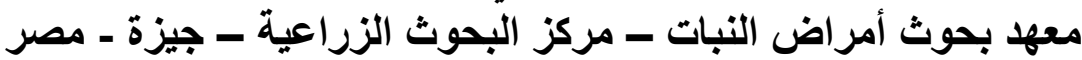

تنتشر زر اعة البصل انتشار او اسعا حول العالم ، حيث تدخل الابصال فى العديد

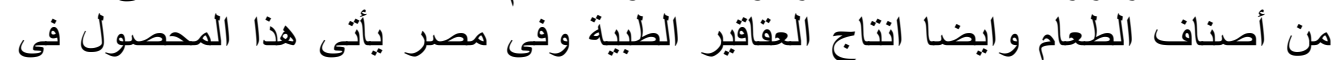

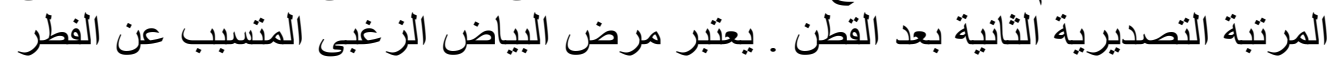

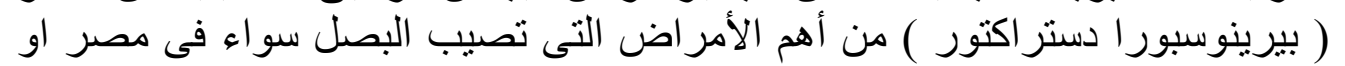

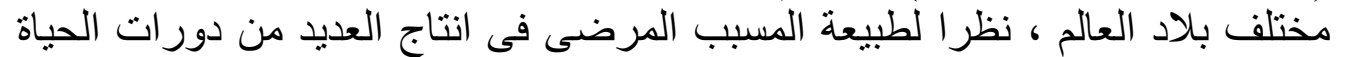

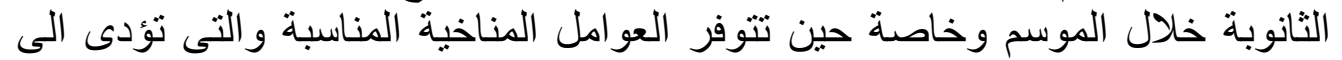

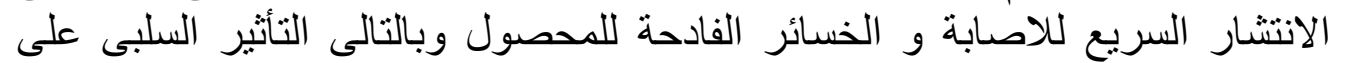

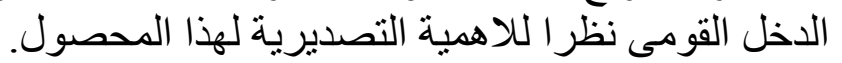

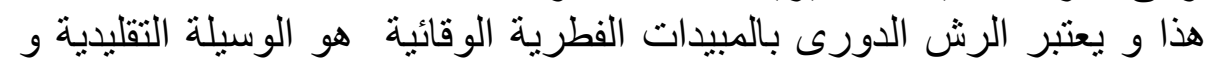

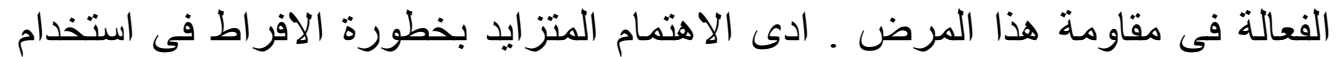

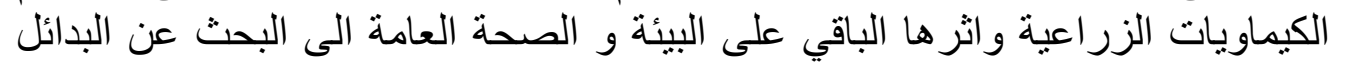

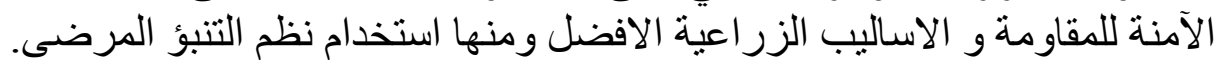

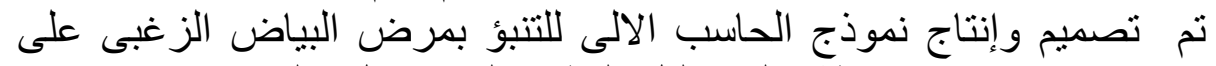

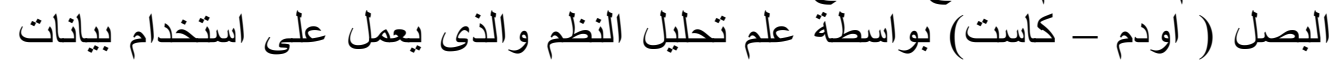

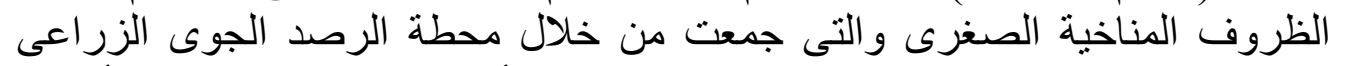

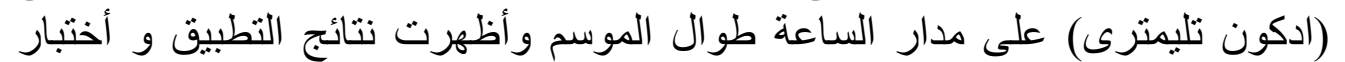

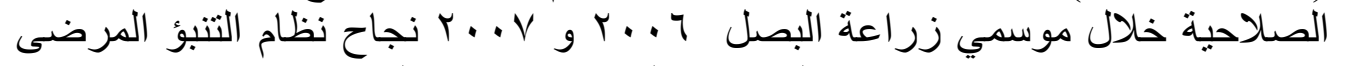

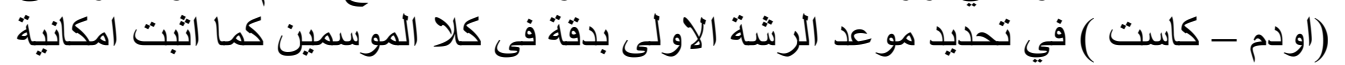

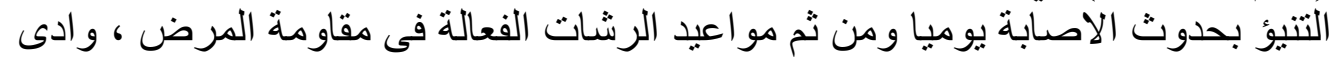

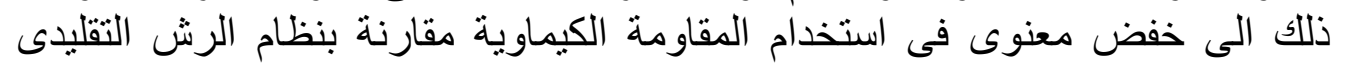

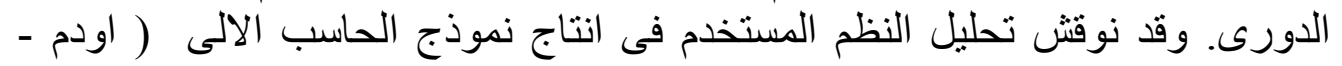

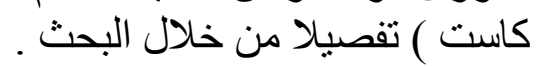

